\title{
Simulation and Games Based Learning Model for Learning Math in Higher Education
}

\author{
Pratiwi $^{1,2, *}$, Lucia Sri Istiyowati ${ }^{1,2}$ \\ ${ }^{1}$ Faculty of Information Technology, Perbanas Institute, Jakarta, Indonesia \\ ${ }^{2}$ Faculty of Educational Technology, Universitas Negeri Jakarta, Jakarta, Indonesia
}

Received December 10, 2019; Revised June 20, 2020; Accepted July 29, 2020

\section{Cite This Paper in the following Citation Styles}

(a): [1] Pratiwi, Lucia Sri Istiyowati, "Simulation and Games Based Learning Model for Learning Math in Higher Education," Universal Journal of Educational Research, Vol. 8, No. 9A, pp. 16 - 20, 2020. DOI: 10.13189/ujer.2020.082003.

(b): Pratiwi, Lucia Sri Istiyowati (2020). Simulation and Games Based Learning Model for Learning Math in Higher Education. Universal Journal of Educational Research, 8(9A), 16 - 20. DOI: 10.13189/ujer.2020.082003.

Copyright $₫ 2020$ by authors, all rights reserved. Authors agree that this article remains permanently open access under the terms of the Creative Commons Attribution License 4.0 International License

\begin{abstract}
Learning in mathematical subjects such as calculus, engineering mathematics, statistics, discrete mathematics, numerical methods, etc., is necessary for proper learning so students understand well. In this study, the lecturer will improve the pedagogical process, which involves at least three aspects of the process: construction, reflection, and communication. The simulation method is a learning method that is done by giving students aspects of construction and reflection. The game method supports aspects of communication and reflection because it makes students motivated by learning in different atmospheres, conditions and enthusiasm. The two methods are combined and supported by the use of mathematics information and communication technology (ICT) learning processes. The learning model uses simulations and games because the learning process during teaching and learning activities that involve educators and students. The results of research at Faculty of Information Technology Perbanas Institute Jakarta students show that student motivation has increased in terms of attendance and enthusiasm in attending lectures and in evaluating student learning outcomes has increased in final exam result.
\end{abstract}

Keywords Math, Simulation, Games, User Model Learning

\section{Introduction}

STEAM education (Science, Technology, Engineering,
Art, and Mathematics / science, technology, engineering, art, and mathematics) is gaining in popularity but there is little empirical data to guide effective learning practices, and even little is known about the challenges associated with teaching [1].

Learning subjects in the field of mathematics (clusters) of mathematics such as calculus, engineering mathematics, statistics, discrete mathematics, numerical methods the need for proper learning so that students understand well. The initial abilities possessed by students before starting to follow the subject / subject in mathematics are not the same. This can be seen from the educational background possessed by students before entering college. Examples for some exact sciences study programs such as in the information technology faculty that have students who come from non-exact vocational students or from high school with a social science background. This causes problems in providing mathematics teaching courses which are categorized as "difficult" science. As observations made by Gay's $(2002,2013)$ educators highlight the process of understanding and mastering the ability of mathematics, natural sciences, culture and language by emphasizing on acting and thinking in 4 scopes namely 1) changing attitudes and beliefs in learning 2) environmental and cultural influences 3) wrestling in resistance 4) increasing linkages with pedagogics. [2]. The results of this study indicate the importance of learning by paying attention to the contents of the material, repetition or reproducing exercises and focus. For that we need a form of learning that is appropriate for the conditions mentioned above. 
In learning mathematics, educators / lecturers play a role in improving the pedagogic process, which must involve at least three aspects of the process, namely; construction, reflection, and communication. Construction aims to educators "experience" learning, and reflection aims to internalize knowledge that has been constructed, and communication aims to make knowledge become meaningful information. [3]

Mathematical learning can be through 1) visualization of teaching materials 2) learners doing exercises, repeating material 3) variations of teaching materials 4) creative teaching methods from educators. Of the four things above, it is necessary to have a learning model for users which is interesting and creative with the support of information technology so that students get visualization of teaching material and practice the teaching material repeatedly given [4].

Mathematics learning is not only oriented towards the final result, but emphasizes more on the process during teaching and learning activities that take place involving educators and students. The involvement of educators is of course important, of course, with the support of technology, appropriate learning models are created for the above problem. Progress in science and technology is clearly needed in order to be able to achieve the objectives of learning in general, as well as for learning in the field of mathematical science. In addition to considering various other factors that influence such as curriculum, learning process, teaching methods, evaluations, textbooks, teacher quality, education advice and infrastructure. [5]

\section{Materials and Methods}

\subsection{Materials}

In various disciplines, it is necessary to choose a model to be used in the design process. Models can be: Evaluative if the model is used to evaluate existing designs Generative if the model has contributed to the design process. And in practice, the model that is often used is generative. User models in an interaction system are represented in the cognitive model and consist of a hierarchical model that represents the user's task and goal structure. Linguistic models that represent the user system grammar, as well as physical models and devices that represent human motor skills.

According to Rachel (2015) there are 5 considerations in determining mathematical learning models, namely:

1. Solving memorization problems for mathematical formulas that are considered boring.

2. Nobody feels comfortable if they are wrong in working/solving mathematical problems.

3. Problem stories that are difficult to understand. Then modeling becomes important for end-users to understand something or make a decision.
4. Math is difficult and requires practice. Modeling presents problem-solving as a creative, repetitive process.

5. The myth that the mastery of mathematics is considered intelligence itself is not a group.

Therefore the modeling problem has many possible answers justified. and must present a problem-solving repeatedly also in learning should be done in groups or teams. [6] There are several types of user models in mathematics learning both directly and cooperatively. In general, the model used is direct learning from educators to students. Existing cooperative models such as Student Team Achievement Division, Jigsaw, Group Investigation go around, Think pair and share, Make a match, Number Heads Together, Team Assisted Individualization, Pair check, Simulation, Games (Games) and many others.

The simulation method is a learning method that is done by giving participants to students through imitation behavior or playing roles with the aim that students are able to match the truth. In its implementation in learning mathematics, the simulation method provides an opportunity for students/students to learn dynamically and interactively, both individuals and groups. Students/students are given a complete mindset stimulation based on approved learning experiences and actual problem-solving. Simulation Method is the development of learning methods carried out by forming discussion groups of students/students who play an active and critical role in accordance with their respective tasks, including playing as a simulator (part of the simulation method) as well as questioners, supporters, opponents and givers example.

Besides simulating the use of mathematical learning methods, using the game method. The choice of game method because this method is rarely used to discuss mathematical material. In addition, the expected game method is suitable for use in mathematical material for students/students. The game method can help increase student motivation to look un-concentrated on the lessons received and then be transferred to the game method for a certain amount of time until they return [7]

Using the game method effectively expected against student motivation. Using the game method will make students learn with a different atmosphere, and enthusiasm, ie learn mathematics directly, not only count abstract learning to learn mathematics while playing. Student motivation to increase learning outcomes will also increase. Play and learn to have several differences, which can change behavior, attitude, and experience. Changes in behavior and a positive attitude can help in the process supported by the motivation of students. Learning will be effective and approved by students motivated to learn so that the objectives in the learning process can be done well. The subject matter delivered can not only be learned and added but also be knowledge. In addition, learning will make students creative and can communicate with 
their opinions [8].

In the world of education, supporting Information and Communication Technology (ICT) devices greatly help the teaching and learning process. The results of research released by Computer Technology Research that a person will only get $20 \%$ of what they see and $30 \%$ of what they hear. While multimedia will get $50 \%$ of what they see and hear up to $80 \%$ of what they see, hear and play at the same time [5]. By using multimedia-based simulations, it is expected that elementary level students in tertiary institutions with diverse basic knowledge of mathematical knowledge can achieve learning objectives according to the required competency standards.

In this research, studying mathematics using games that are conducted in a school environment with explored mathematics games. Described a study of Monkey Tales games, which is an educational math game targeted at elementary school children. Using a combination of multimodal game analysis and six-month user studies with eight children aged 10-11 and their families, a detailed description of how the Monkey Tales game right at home is obtained. It investigated that players develop tactics for the right game that suits their personal interests. It explained the implications for generalizing research into effectiveness, and for educational game design. [9]. Learning mathematics by using games / games can be applied to students in college because basically everyone likes games. Research conducted by Paiva [10] observes how learners interacting on-line can improve their learning experience.

Educational games that have developed rapidly in the last decade have proven to have many benefits. However, only a few proposed a methodology for the development of educational video games. Research conducted by Lopez, Medina, Paderewski [12] presents a new methodology for developing educational games based on graphic notation and divided into six stages: chapter design, scene design (screenplay, characters, actions and dialogue), design of educational challenges in games, adaptation design, design from emotional experience and collaboration design.

\subsection{Methods}

The research method used in this study is Classroom Action Research, which is a form of research that occurs in the classroom in the form of certain actions taken to improve teaching and learning in order to improve learning outcomes better than before. The steps of the research carried out are shown in Figure 1.

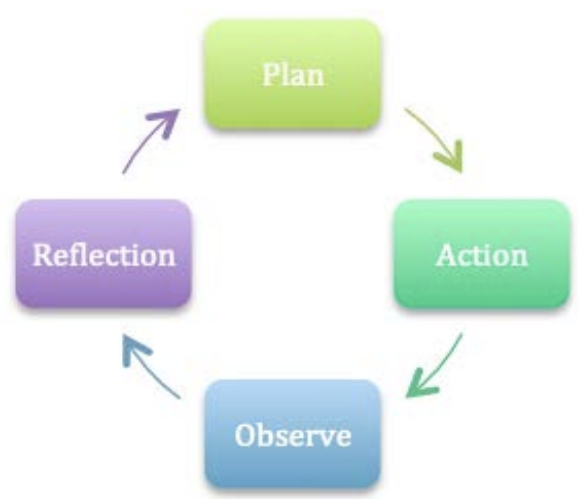

Figure 1. Steps of research

The research conducted on the even semester 2015/2016 at the researcher place of teaching by doing a combination of simulations and games on mathematics family courses (Discrete Mathematics, Numerical Methods and Calculus). Researcher identify existing problems to be the basis for identifying needs. Conducted by interviews with stakeholders and students related to this subject. Student said they are bored with classical learning. They need some different atmosphere that is not binding or rigid in the teaching and learning process. Researchers and participants work together to understand the main problems.

Plan, preparing appropriate action plans to resolve existing problems and began to sketch the original and determine the content that will be done later. Reseacher would use games and simulation such as strategy to transfer content in learning mathematics for 24 student in Perbanas Institute Jakarta as participant.

As for Action, researchers and participants jointly implement an action plan in the hope of resolving the problem. Furthermore, after the model is made based on sketches and adjusts the content to be displayed based on needs, it is continued by conducting initial trials. Researcher made game design in accordance with the aim and facilitating for the implementation.

As for Observe, after the implementation period of the action, it is considered sufficient then the researcher along with the participants carrying out observations of the results of this stage seen how the acceptance of game users and simulations are characterized by increased motivation to participate in learning activities.

As for Reflection, researchers should analyze, synthesize, interpret, explain and conclude. The results of the reflection activity are information that participant (student) enjoyed learning with games and simulation on subject mathematics and teacher needs to improve games and simulation activity. 


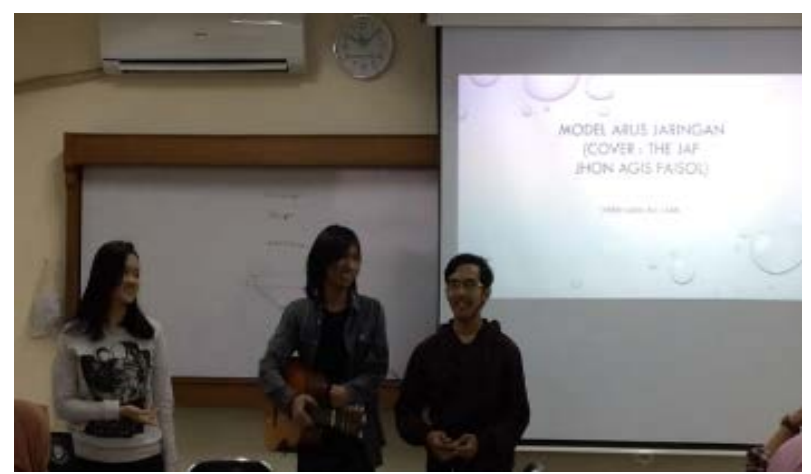

personalize the approach to more than two user groups from the environment was studied. Researcher observes how learners interacting can improve their learning experience.

Learning analytics is an emerging field focusing on analyzing student interactions with educational content. This is a very challenging problem in games that produce a variety of data. The educational games have many benefits. Furthermore, important concepts when designing the game and evaluating it, including the expected emotional reactions, are discussed in another case study.

The author conducted a class action research on the even semester 2015/2016 at the author's place of teaching by doing a combination of simulations and games on mathematics family courses (Discrete Mathematics, Numerical Methods and Calculus). The results showed that students' motivation increased viewed from the attendance and enthusiasm of students in attending lectures and in terms of evaluating student learning outcomes which increased on the final test results compared to the midtest score.

\section{Conclusion}

Learning the field of mathematics in higher education that teaches students with diverse educational backgrounds (not all have the same competency standards for mastery of basic mathematics), learning models must be conducted in accordance with the characteristics of these students. The user model created demands that educators (lecturers) have creativity and innovation in their learning. The model uses simulation methods and games to be an alternative in the learning process carried out in tertiary institutions. Because the learning process is not only oriented towards the final result but is more focused on the process during teaching and learning activities that take place involving educators and students. The involvement of educators in learning is important with the support of technology and attention to the characteristics of students so that learning models are made in accordance with the situations and problems encountered. (games) conducted in the school environment with explored mathematics games. However, the home environment through educational games, investigated that players develop tactics for the right game that suits their personal interests. Learning mathematics by using games can be applied to students in college because basically everyone likes games.

An approach to model and analyze student interactions, in an games simulation help teachers and tutors (education professionals) make decisions, regarding learners' learning experiences. It appears that educational resources available in the environment can be studied, and data collected that students interact with these resources. The aim is to produce an interaction profile for students (their interaction model). In this study, the type of interaction used to

\section{REFERENCES}

[1] D. Herro, C. Quigley, and H. Cian, "The Challenges of STEAM Instruction: Lessons from the Field,” Action Teach. Educ., vol. 41, no. 2, pp. 172-190, Apr. 2019.

[2] S. I. Bottoms, K. Ciechanowski, K. Jones, J. de la Hoz, and A. L. Fonseca, "Leveraging the community context of Family Math and Science Nights to develop culturally responsive teaching practices,” Teach. Teach. Educ., vol. 61, pp. 1-15, Jan. 2017

[3] I. N. Parta, "Desain Pembelajaran Matematika Bagi Calon 
Guru Matematika,” 2009.

[4] M. Klement, "Models of integration of virtualization in education: Virtualization technology and possibilities of its use in education,” Comput. Educ.

[5] A. Syafrizal, Ernawati, and B. Y. Dwiandiyanta, "Penerapan Model TAM untuk Pemahaman Media Pembelajaran Berbasis Multimedia Interaktif,” Sci. J. Inform., vol. 2, no. no 1, Mei 2015.

[6] L. Rachel, "5 Reason to Teach Mathematical Modeling." 12-Nov-2016.

[7] I. N. Parta, "Matematics Learning Design for Pre-Service Mathematics Teacher.” 2009.

[8] A. Hamzah and Muhlisrarini, "Perencanaan Strategi Pembelajaran Matematika.”
[9] J. Derboven, B. Zaman, D. Geerts, and D. De Grooff, "Playing educational math games at home: The Monkey Tales case,” Entertain. Comput., vol. 16, pp. 1-14, Jul. 2016.

[10] R. Paiva, I. I. Bittencourt, T. Tenório, P. Jaques, and S. Isotani, "What do students do on-line? Modeling students' interactions to improve their learning experience," Comput. Hum. Behav., vol. 64, pp. 769-781, Nov. 2016.

[11] Á. Serrano-Laguna, I. Martínez-Ortiz, J. Haag, D. Regan, A. Johnson, and B. Fernández-Manjón, "Applying standards to systematize learning analytics in serious games,” Comput. Stand. Interfaces, vol. 50, pp. 116-123, Feb. 2017.

[12] R. P. de Lope, J. R. López Arcos, N. Medina-Medina, P. Paderewski, and F. L. Gutiérrez-Vela, "Design methodology for educational games based on graphical notations: Designing Urano,” Entertain. Comput., vol. 18, pp. 1-14, Jan. 2017 